\title{
Osteomalacia in rheumatoid arthritis
}

\author{
SUSAN O'DRISCOLL AND MICHAEL O'DRISCOLL
}

From the Orthopaedic Department, Bristol Royal Infirmary

SUMMARY Fifty-four patients with rheumatoid arthritis and severe osteomalacia were found to have considerable bone and general deficiency problems. In 46 of them 14 stress fractures occurred and 32 minimal trauma fractures necessitating admission to hospital. Radiological abnormalities of absorption were found in nearly $25 \%$ of the total, implying that dietary factors alone are not always responsible for osteomalacia in patients with rheumatoid arthritis. A high index of suspicion is necessary in the diagnosis of osteomalacia in patients with rheumatoid arthritis, so they may benefit from treatment.

Spontaneous and stress fractures have been reported in patients with rheumatoid arthritis (RA), whether or not they were receiving steroids (Haider and Storey, 1962; Taylor et al., 1971). Generalised osteoporosis has been considered important in their aetiology. Osteomalacia in RA has been reported infrequently, but Maddison and Bacon (1974) reported 5 cases of $\mathrm{RA}$ with osteomalacia presenting with spontaneous fractures. They drew attention to its occurrence and how easily it may be overlooked. In their series dietary deficiency was thought to be the major cause of the osteomalacia.

The elderly British population has been shown to be in a chronic state of hypovitaminosis D (ExtonSmith et al., 1966; Chalmers et al., 1967; Stanbury et al., 1970). This is due to dietary inadequacies of vitamin D and the geographical position of Great Britain in relation to the ultraviolet in sunlight.

Osteomalacia occurs in malabsorption states (Salveson and Boe, 1973), renal disease (Fourman and Royer, 1968); liver disease (Sherlock et al., 1966), and during anticonvulsant therapy with phenytoin (Kruse, 1968). The symptoms of osteomalacia are well known, consisting of weakness, lassitude, and bone pain in severe cases. These symptoms of osteomalacia may be overlooked in the plethora of other symptoms in RA.

Recent work on proximal femoral fractures (Chalmers, 1970; O'Driscoll, 1973; Jenkins et al., 1974) has shown how common osteomalacia is among elderly people with fractures. Orthopaedic departments see most of the cases that present as pathological fractures.

Accepted for publication 27 April 1978

Correspondence to $\mathrm{Mr} \mathbf{M}$. O'Driscoll, FRCS, Leighton Hospital, Leighton, Crewe CW1 4OJ.
The present study is based on 54 patients with RA and osteomalacia leading to pathological fracture or severe bone pain seen in the Orthopaedic Department at Bristol Royal Infirmary over a period of $2 \frac{1}{2}$ years.

\section{Patients and methods}

Fifty-four patients with RA and severe osteomalacia without any renal or liver disease who presented to the Orthopaedic Department at Bristol Royal Infirmary with pathological fractures or severe bone pain over a period of $2 \frac{1}{2}$ years were studied. There were 48 females and 6 males, the average age was $62 \pm 7$ years. They had all had RA for a minimum of 10 years. None of the 54 patients were receiving anticonvulsant therapy.

All 54 patients had received steroids at some stage of their disease. Twenty-one were on steroids at the time of presentation. All the patients had received most of the common anti-inflammatory drugs at some stage of their disease. Nine patients had had chrysotherapy, but none had been given penicillamine or cytotoxic agents. The majority of the 54 patients presented with pathological and stress fractures, the rest with generalised bone pain (Table 1).

\section{Table 1 Presentation of patients}

\begin{tabular}{lc}
\hline Symptoms & Number \\
\hline Pelvic fracture & 16 \\
Proximal femoral fracture & 8 \\
Tibial fractures & 8 \\
Stress fracture & 14 \\
Generalised bone pain & 8 \\
Total & 54 \\
\hline
\end{tabular}


Seven of the 54 patients, 3 male and 4 female, had undergone partial gastrectomy in the past. These 7 all presented with proximal fractures of the femur.

\section{INVESTIGATIONS}

Haematological and chemical pathological investigations were performed on all 54 patients. All the patients had haemoglobin estimation and a full blood count performed. Serum calcium, with correction for protein (Dent, 1962), phosphorus and alkaline phosphatase and protein levels were measured. Urea and electrolytes were determined, and all patients had a 24-hour creatinine clearance test performed. Serum iron and total iron binding capacities (TIBC), serum $B_{12}$, and red cell folate levels were measured. Liver function tests including 5 nucleotidase levels were performed, as was a 5hour xylose excretion test.

If the 5-hour xylose excretion test was abnormal, 3-day faecal fat studies were performed, and a small bowel follow-through barium meal was obtained, except in the 7 patients who had had previous partial gastrectomy. If the $\mathbf{B}_{12}$ level was low a Schilling test was carried out. All patients had 24hour collections of urine for calcium excretion for 2 days and a modified Whittle vitamin D saturation test (Whittle et al., 1969) modified by O'Driscoll (1973).

Skeletal surveys were carried out on all the patients. In the absence of Looser zones, which were taken as diagnostic of osteomalacia, bone biopsy from the iliac crest was performed either on its own or during operation.

\section{Results}

\section{RADIOLOGY}

All 54 patients had severe loss of bone density and were diagnosed as being osteoporotic; 39 had Looser zones, 31 being multiple.

Looser zones (Fig. 1) are diagnostic of osteomalacia (Milkman, 1930; Fourman and Roger, 1968; Chalmers, 1970), the differential diagnosis of these pseudofractures being the infractions of Paget's disease and stress fractures occurring in fragilitas ossium. Paget's disease was not present in any of these patients and none had the rare disease of fragilitas ossium.

Table 2 Sites and numbers of Looser zones

\begin{tabular}{lc}
\hline Site of Looser zone & Number of patients \\
\hline Pelvis & 4 \\
Ribs & 4 \\
Multiple sites & 31 \\
Total & 39 \\
\hline
\end{tabular}

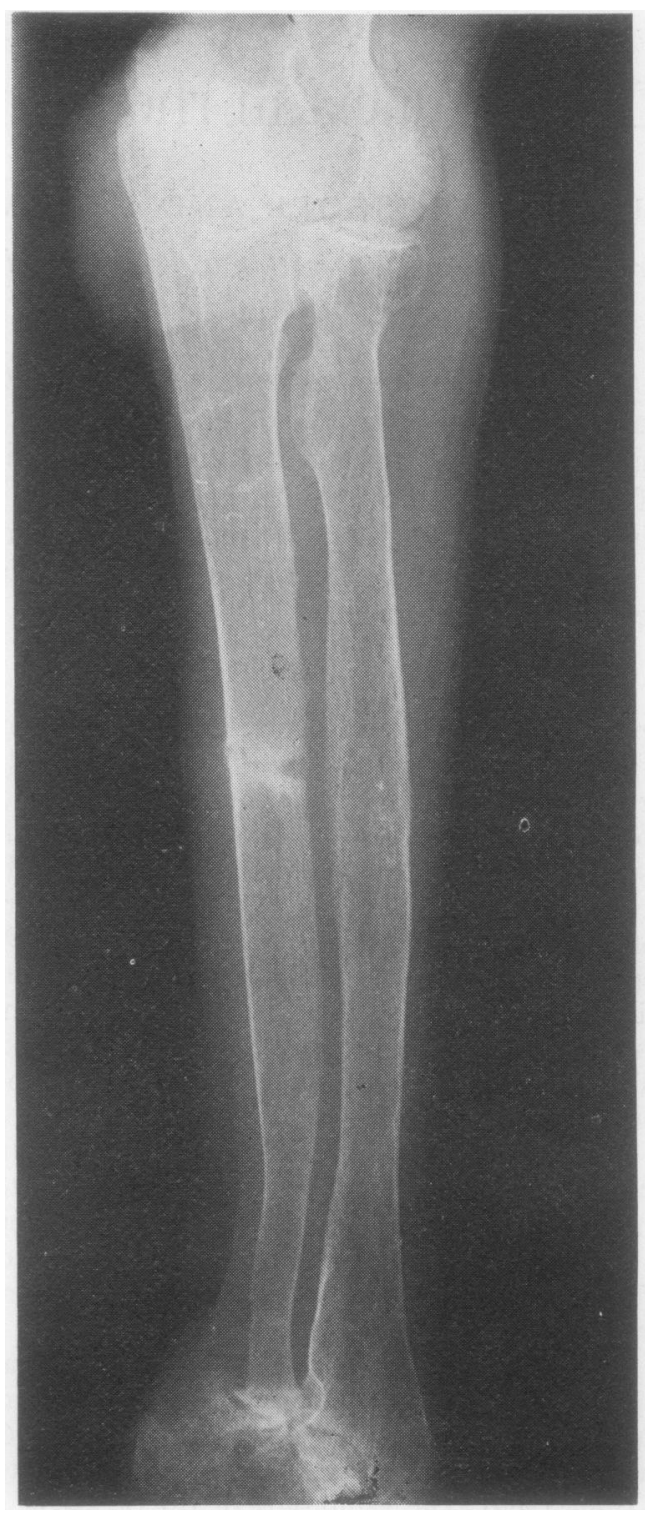

Fig. 1 Looser zone in the forearm of a patient with rheumatoid arthritis: note destruction of wrist

Multiple Looser zones were present in 31 of the 54 patients (Table 2). So-called steroid or osteoporotic stress fractures were seen in 16 patients; all of these 16 had Looser zones elsewhere. Fig. 2 shows a stress fracture in a fibula with a Looser zone in the contralateral femur (Fig. 3), and some 5 days later a spontaneous fracture is shown. Fig. 4. 


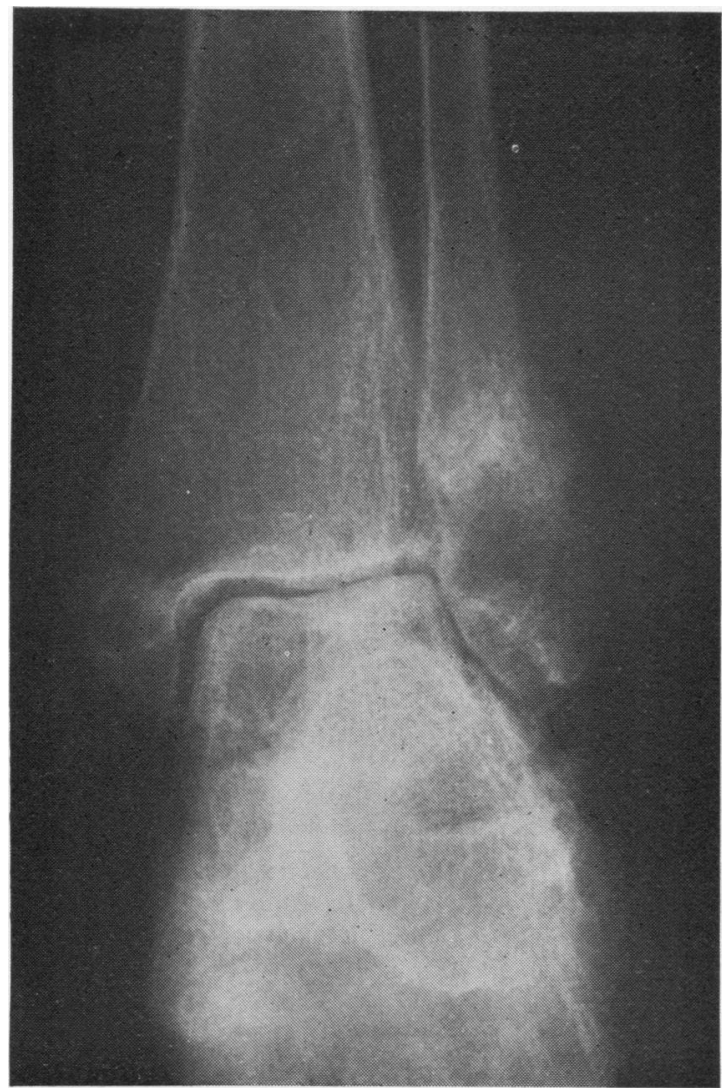

Fig. 2 Apparent stress fracture in a patient with rheumatoid arthritis

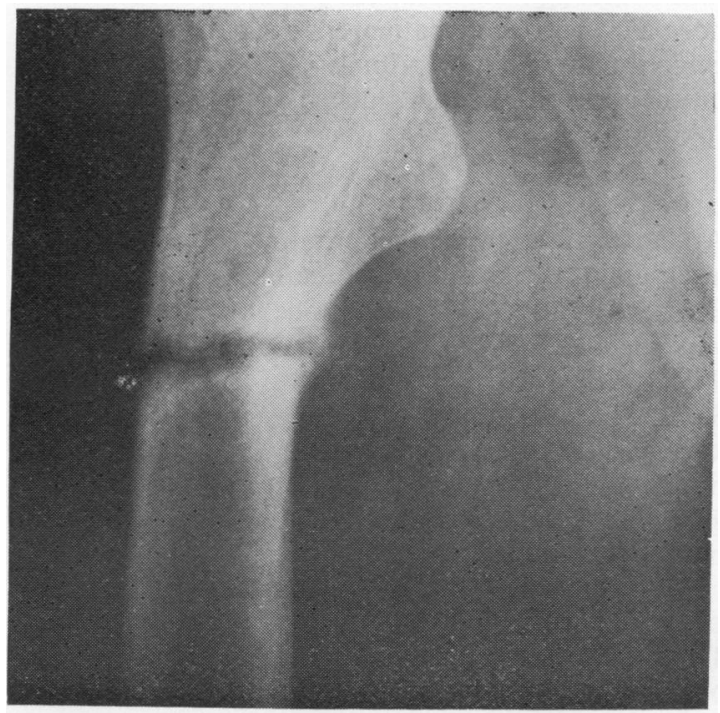

Fig. 3 Looser zone of femur before fracture

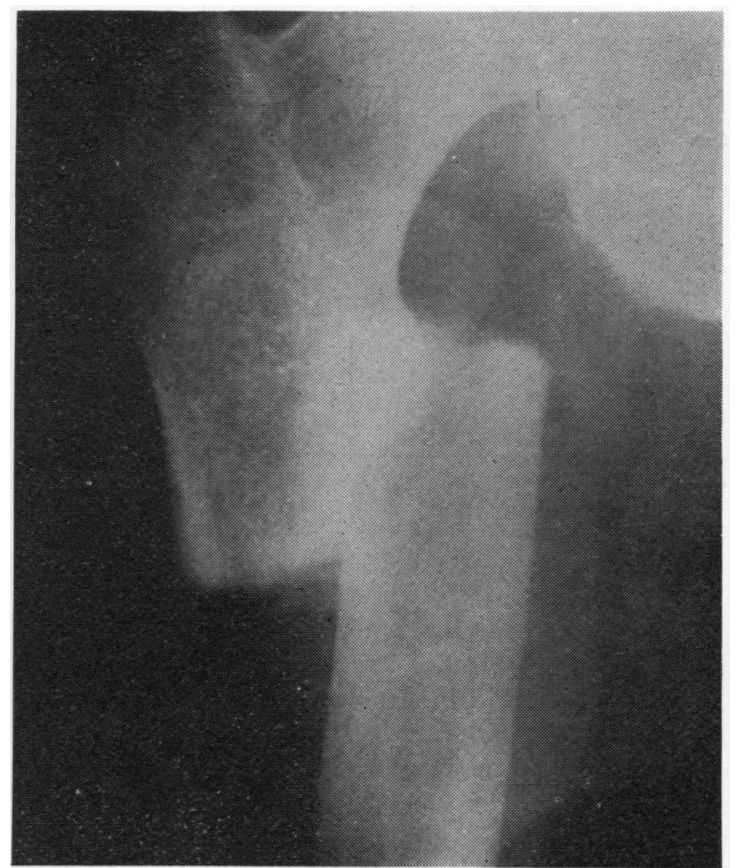

Fig. 4 Same patient after Looser zone had given way to become a complete fracture

\section{HAEMATOLOGY}

The results of the patients' haemoglobin film, serum iron, total iron binding capacity, serum $B_{12}$, and red cell folate are shown in Table 3 . Only 14 patients had low serum $B_{12}$. All of these had an abnormal Schilling test. All 7 patients who had undergone partial gastrectomy fell in this group.

\section{CHEMICAL PATHOLOGY}

Urea and electrolytes were normal in all the patients, as were their bilirubins, transaminases, and 5nucleotidase. The abnormal results obtained for calcium, phosphate, calcium/phosphate product, alkaline phosphatase, total protein, and 24-hour urinary calcium excretion are shown in Table 4.

Table 3 Haematological results

\begin{tabular}{|c|c|c|c|}
\hline Test & Mean & $\begin{array}{l}\text { Standard } \\
\text { deviation }\end{array}$ & Normal \\
\hline $\begin{array}{l}\text { Haemoglobin } \\
\text { Film }\end{array}$ & $\begin{array}{l}11.9 \mathrm{~g} / \mathrm{dl} \\
\text { Normal } 48 \text { patients, } \\
\text { microcytic } 5 \\
\text { patients, megalo- } \\
\text { blastic } 1 \text { patient }\end{array}$ & 0.5 & \\
\hline $\begin{array}{l}\text { Serum iron } \\
\text { TIBC } \\
\text { B }_{12} \\
\text { Red cell folate }\end{array}$ & $\begin{array}{l}29.4 \mu \mathrm{g} / 100 \mathrm{ml} \\
234 \mu \mathrm{g} / 100 \mathrm{ml} \\
125 \mu \mathrm{g} / 100 \mathrm{ml} \\
134 \mu \mathrm{g} / 100 \mathrm{ml}\end{array}$ & $\begin{array}{l}9 \cdot 8 \\
12 \\
37 \\
31\end{array}$ & $\begin{array}{l}120-250 \\
200-350 \\
\text { Above } 166 \mu \mathrm{g} \\
\text { Above } 166 \mu \mathrm{g}\end{array}$ \\
\hline
\end{tabular}


Table 4 Chemical pathology

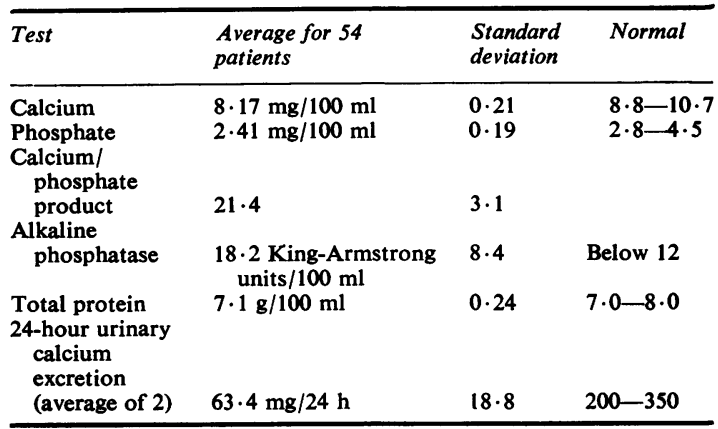

Conversion to SI: Calcium $1 \mathrm{mg} / 100 \mathrm{ml}=0.25 \mathrm{mmol} / 1$. Phosphate $1 \mathrm{mg} / 100 \mathrm{ml}=0.323 \mathrm{mmol} / \mathrm{l}$. Total protein $1 \mathrm{~g} / 100 \mathrm{ml}=10 \mathrm{~g} / \mathrm{l}$. 24-hour urinary calcium $1 \mathrm{mg} / 24 \mathrm{~h}=0.025 \mathrm{mmol} / 24 \mathrm{~h}$.

Thirty-four of the 54 patients had xylose excretion below $25 \%$ (normal $>25 \%$ excretion). Of these 34 patients with abnormal xylose excretion 7 had had partial gastrectomy, leaving 27 patients without previous gastrointestinal surgery with RA and abnormal xylose excretion tests. None of these patients had abnormal results for their 3-day faecal fats.

\section{MODIFIED WHITTLE TESTS}

All 54 patients had a modified Whittle test performed (Whittle et al., 1969) modified by O'Driscoll (1973). The Whittle test consists of an intravenous load of vitamin $D_{3}$ and estimation of the serum phosphate before the injection and again at 4 days. If the serum phosphate rises by more than $25 \%$, vitamin $\mathbf{D}$ deficiency is indicated. The modification used is an oral daily load of 50000 units of vitamin D for 7 days with measurement of the serum phosphate at the beginning and end of the test. A rise in serum phosphate of $25 \%$ or over is indicative of vitamin $\mathbf{D}$ deficiency.

All 54 patients in the present study responded by a rise of $50 \%$ or more in serum phosphate after 7 days.

\section{BONE BIOPSY SPECIMENS}

Fifteen bone biopsy specimens were examined by von Kossa staining of undecalcified sections, 3 or more osteoid lamellae being suggestive of osteomalacia (Woods, 1966). The largest number of lamellae was 4, the maximum 7 (Table 5).

Table 5 Osteoid lamellae

\begin{tabular}{lllll}
\hline $\begin{array}{l}\text { Number } \\
3\end{array}$ & 4 & 5 & 6 & 7 \\
\hline 1 & 5 & 6 & 2 & 1 \\
\hline
\end{tabular}

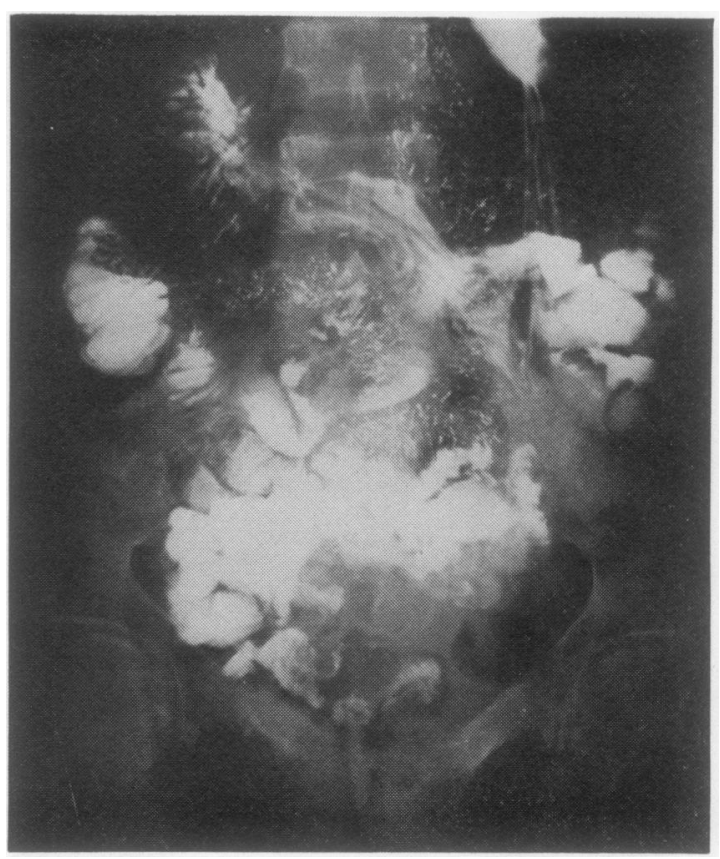

Fig. 5 Small bowel meal of patient with osteomalacia. Looser zone in pelvis; shows flocculation, segmentation, and dilatation of small bowel. Radiological malabsorption pattern

\section{ABSORPTION STUDIES}

The 27 patients with RA who had abnormal xylose excretion without previous partial gastrectomy underwent barium studies with a small bowel follow-through examination. Fourteen of these were normal. Thirteen patients showed radiological evidence of malabsorption with flocculation, dilatation, and segmental thickening of the mucosal fold (Fig. 5).

\section{DIET}

An assessment of dietary vitamin D content was attempted by means of the tables and values in Samson-Wright (1961). In none of these patients was the dietary intake of vitamin $D$ greater than 90 IU a day, average intake $44 \pm 15$. However, of 50 other patients without RA presenting for hip and knee surgery in the same period none had an intake of adequate vitamin $D$. Their average was $49 \pm 17$. These patients all had dietary vitamin $D$ deficiency but none had osteomalacia.

\section{ULTRAVIOLET EXPOS URE}

This could not be measured. Just over half (28) patients were totally house bound, and the remainder were only less so. 


\section{Discussion}

All 54 patients had RA with evidence of osteomalacia. Thirty-two patients developed fractures precipitating their presentation. Fracture of major bones is a catastrophe to the patient with RA, the sequelae of which led to the death of 4 patients out of the 54 studied and permanent loss of ambulatory function in 5 patients.

Osteomalacia was associated with stress fractures in 14 patients and bone pain in 8 patients. Osteomalacia must always be considered as a possible cause of stress fractures and must be excluded. Maddison and Bacon (1974) have drawn attention to this and the present study reinforces the fact that osteomalacia may be one of the underlying factors in stress and spontaneous fractures in patients with RA.

Dietary deficiency of vitamin D certainly played a major part in the causation of the osteomalacia, but absorption abnormalities were found in a proportion of cases. Absorption abnormalities of the small bowel have been found in RA (Toivonen et al., 1964; Siurala et al., 1965; Patterssen et al., 1970). Malnutrition itself may cause malabsorption (Herskovic, 1969), as may the drugs used for the treatment of RA, which may also cause malabsorption (Falcon and Saunders, 1968; Kendall et al., 1971).

A high incidence of haematological abnormalities were found in these patients in spite of normal blood counts, and this emphasises their deficiency problems. Certainly the 54 patients studied had dietary deficiencies in addition to the other effects of their rheumatoid arthritis. Gastric upsets due to anti-inflammatory agents, difficulty in feeding and preparing food, and their relatively poorer economic situation all tended to increasing deficiency problems. Dietary supplementation of vitamin D would seem to be mandatory in this group of patients. They also had little exposure to ultraviolet light because of their lack of ambulation and being house bound.

In the present series deficiencies of diet have been found to be associated with abnormalities of absorption. This amounted to nearly $25 \%$ (13 out of 54) who had absorption abnormalities as shown by the barium studies. One of these patients had a large bowel malignancy from which she eventually died. Osteomalacia in patients with RA may be commoner than is recognised and can easily be mistaken for osteoporosis. Looser zones appear late in osteomalacia and nonspecific loss of bone density may be the only early feature. this being common to both osteoporosis and osteomalacia.

Certainly all patients with RA who develop spontaneous stress fractures should be extensively investigated for osteomalacia, including a bone biopsy if necessary, before a diagnosis of osteoporosis is acceptable. Osteomalacia is easily treated and may by its treatment stop further development of spontaneous or stress fractures. Further, it must not be assumed that dietary deficiency is the only cause of osteomalacia in a patient, since a careful search may reveal other disease. No conclusions as to the incidence of osteomalacia in RA may be drawn from this series except that it can occur, and dietary causes may not be the only factors.

We thank Dr Arthur L. Eyre-Brook and Mr H. K. Lucas for allowing us to study their patients, Mr Graham Moore, chief technician, and his staff, and Dr P. Bacon for his advice.

\section{References}

Chalmers, J. (1970). Subtrochanteric fractures in Osteomalacia. Journal of Bone and Joint Surgery, 52B, 509-513.

Chalmers, J., Conacher, W. D. H., Gardiner, D. L., and Scott, P. J. (1967). Osteomalacia-a common disease in elderly women. Journal of Bone and Joint Surgery, 49B, 403-422.

Dent, C. E. (1962). Some problems of hyperparathyroidism. British Medical Journal, 2, 1495-1500.

Exton-Smith, A. N., Hodkinson, H. M., and Stanton, B. R. (1966). Nutrition and metabolic bone disease in old age. Lancet, 2, 999-1001.

Faloon, W. W., and Saunders, D. G. (1968). Intestinal malabsorption: process in diagnosis and treatment. New York Medical Journal, 68, 2552-2555.

Fourman, P., and Royer, P. (1968). Calcium Metabolism and the Bone, 2nd edn., pp. 296, 113, Blackwell: Oxford.

Haider, R., and Storey, G. (1962). Spontaneous fractures in rheumatoid arthritis. British Medical Journal, 1, 942-9.

Herskovic, T. (1969). Protein malnutrition and the small bowel. American Journal of Clinical Nutrition, 22, 300304.

Jenkins, D. H. R., Roberts, J. G., Webster, D., and Williams, E. G. (1974). Osteomalacia in elderly patients with fractures of the femoral neck. Journal of Bone and Joint Surgery, 55B, 575-580.

Kendall, M. J., Nutter, S., and Hawkins, C. F. (1971). Xylose test-Effect of aspirin and indomethacin. British Medical Journal, 1, 533-535.

Kruse, R. (1968). Osteopathien bei antiepileptischer Langzeittherapie. Monatsschrift für Kinderheil kunde, 116, 378381.

Maddison, P. J., and Bacon, P. A. (1974). Vitamin D deficiency, spontaneous fractures, and osteopenia in rheumatoid arthritis. British Medical Journal, 4, 433-435.

Milkman, L. A. (1930). Pseudo-fractures (hunger osteopathy. late rickets and osteomalacia). American Journal of Roentgology, 30, 29-34.

O'Driscoll, M. (1973). The Nature and pathogenesis of the true subcapital fracture. Ch $\mathrm{M}$ thesis, Bristol.

Pettersson, T., Wegelivs, O., and Skrifvars, B. (1970). Gastro-intestinal disturbances in patients with severe rheumatoid arthritis. Acta Medica Scandinavica, 188, 139-144.

Salvesen, H. A., and Boe, J. (1973). Osteomalacia in sprue. Acta Medica Scandinavica, 146, 290-299. 


\section{O'Driscoll, O'Driscoll}

Sherlock, S., Datta, D. V., and Walker, J. G. (1966). Prognosis and treatment of primary biliary cirrhosis. Revue Internationale d'Hépatologie, 16, 217-225.

Siurala, M., Julkenen, H., Toivonen, S., Pelkonen, R., Saxen, E. and Pitkanen. (1965). The digestive tract in collagen disease. Acta Medica Scandinavica, 178, 13-25.

Stanbury, S. W., Jones, M., Lumb, G. A., and Mawer, E. B. (1970). Vitamin D nutrition in man. Journal of Bone and Joint Surgery, 52B, 388.

Taylor, R. T., Huskisson, E. C., Whitehouse, G. H., and Dudley Hart, F. (1971). Spontaneous fractures of the pelvis in rheumatoid arthritis. British Medical Journal, 4, 663-664.
Toivonen, S., Pitkanen, E., and Siurella, M. (1964). Collagen disease associated with intestinal malabsorption and sprue like changes in the intestinal mucosa. Acta Medica Scandinavica, 175, 91-95.

Whittle, H., Blair, A., Neale, G., Thalassinos, M., McLaughlin, M., Marsh, M. N., Peters, T. J., Wedzicha, B., and Thompson, G. B. (1969). Intravenous vitamin D in the detection of vitamin D deficiency. Lancet, 1 , 747-750.

Wright, S. (1961). Textbook of Physiology, 10th edn., p. 446. London.

Woods, C. G. (1966). Histological studies in osteomalacia. Journal of Bone and Joint Surgery, 48B, 188. 